\title{
FORUM
}

Submitted 07.24.2018. Approved 07.19.2019

Evaluated through a double-blind review process. Guest Scientific Editors: Eduardo de Rezende Francisco, José Luiz Kugler, Soong Moon Kang, Ricardo Silva, and Peter Alexander Whigham

Original version

DOI: http://dx.doi.org/10.1590/So034-759020190607

\section{FACTORS AFFECTING THE ADOPTION OF BIG DATA ANALYTICS IN COMPANIES}

\author{
Fatores que afetam a adoção de análises de Big Data em empresas \\ Factores que afectan a la adopción del análisis Big Data en empresas
}

\begin{abstract}
With the total quantity of data doubling every two years, the low price of computing and data storage, make Big Data analytics (BDA) adoption desirable for companies, as a tool to get competitive advantage. Given the availability of free software, why have some companies failed to adopt these techniques? To answer this question, we extend the unified theory of technology adoption and use of technology model (UTAUT) adapted for the BDA context, adding two variables: resistance to use and perceived risk. We used the level of implementation of these techniques to divide companies into users and non-users of BDA. The structural models were evaluated by partial least squares (PLS). The results show the importance of good infrastructure exceeds the difficulties companies face in implementing it. While companies planning to use Big Data expect strong results, current users are more skeptical about its performance.
\end{abstract}

KEYWORDS | Big Data, intention behavior, unified theory of acceptance and use of technology, resistance to use, perceived risk.

\section{RESUMO}

Com a quantidade total de dados duplicando a cada dois anos, o baixo preço da computação e do armazenamento de dados tornam a adoção de análises de Big Data (BDA) desejável para as empresas, como aquelas que obterão uma vantagem competitiva. Dada a disponibilidade de software livre, por que algumas empresas não adotaram essas técnicas? Para responder a essa pergunta, estendemos a teoria unificada de adoção e uso de tecnologia (UTAUT) adaptado para o contexto do BDA, adicionando duas variáveis: resistência ao uso e risco percebido. Usamos a nível da implementação da tecnologia para dividir as empresas em usuários e não usuários de técnicas de BDA. Os modelos estruturais foram avaliados por partial least squares (PLS). Os resultados mostram que a importância de uma boa infraestrutura excede as dificuldades que as empresas enfrentam para implementá-la. Enquanto as empresas que planejam usar Big Data esperam resultados fortes, os usuários atuais são mais céticos em relação ao seu desempenho.

PALAVRAS-CHAVE / Big Data, intenção de usar, teoria unificada de adoção e uso de tecnologia, resistência ao uso, risco percebido.

\section{RESUMEN}

Con la cantidad total de datos duplicándose cada dos años, el bajo precio de la informática y del almacenamiento de datos, la adopción del análisis Big Data (BDA) es altamente deseable para las empresas, como un instrumento para conseguir una ventaja competitiva. Dada la disponibilidad de software libre, ¿por qué algunas empresas no han adoptado estas técnicas? Para responder a esta pregunta, ampliamos la teoría unificada de la adopción y uso de tecnología (UTAUT) adaptado para el contexto BDA, agregando dos variables: resistencia al uso y riesgo percibido. Utilizamos el grado de implantación de estas técnicas para dividir las empresas entre: usuarias y no usuarias de BDA. Los modelos estructurales fueron evaluados con partial least squres (PLS). Los resultados muestran que la importancia de una buena infraestructura excede las dificultades que enfrentan las empresas para implementarla. Mientras que las compañías que planean usar BDA esperan muy buenos resultados, las usuarias actuales son más escépticos sobre su rendimiento.

PALABRAS CLAVE / Big Data, intención de uso, teoría unificada de la adopción e uso de tecnología, resistencia al uso, riesgo percibido. 


\section{INTRODUCTION}

Currently, society generates data about our activities at an exponential rate of growth. This data covers, for example, our mobile phones and their location, any online transactions, the Internet of things, social networks, wearables, etc. Firms that can transform these data into real-time information about their customers gain a substantial competitive advantage (Sivarajah, Kamal, Irani \& Weerakkody, 2016). User data allows firms to know when their customers consume their products, the best times for promotions, and how to improve brand sentiments. Firms using Big Data analytics (BDA) (McAfee \& Brynjolfsson, 2012) can process huge quantities of data, almost in real time, and become leaders in the market.

The adoption, implementation, and management of BDA requires companies to acquire new skills. New career profiles such as data scientist, which combines engineering, statistics, and a deep knowledge of business, are among the most soughtafter jobs nowadays. Employees with these skills help companies mine data generated by the companies themselves and their customers. This changes how decisions are made, favoring a datadriven approach over one based on the personal experience of CEOs (McAfee \& Brynjolfsson, 2012).

Firms using BDA must address the challenges that arise in the so-called data cycle of life: questions about the data themselves, difficulties processing the data, and concerns about data management (Akerkar, 2014; Zicari, 2014). Questions about the data themselves revolve around their volume, variety, velocity, veracity, volatility, value, and visualization. Data processing tasks include the techniques related to data acquisition, storage in databases, cleaning and transforming existing data, correct model selection, and presentation of the results. Finally, proper data management involves ethical considerations, including respect for user privacy and security.

Because decision-making is increasingly data-driven, companies must obtain valuable information in an efficient way from a rapidly changing data environment. This process, detailed by Agrawal, Bernstein, \& Bertino (2011) as it shows in Figure 1.

\section{Figure 1. Big Data processes}

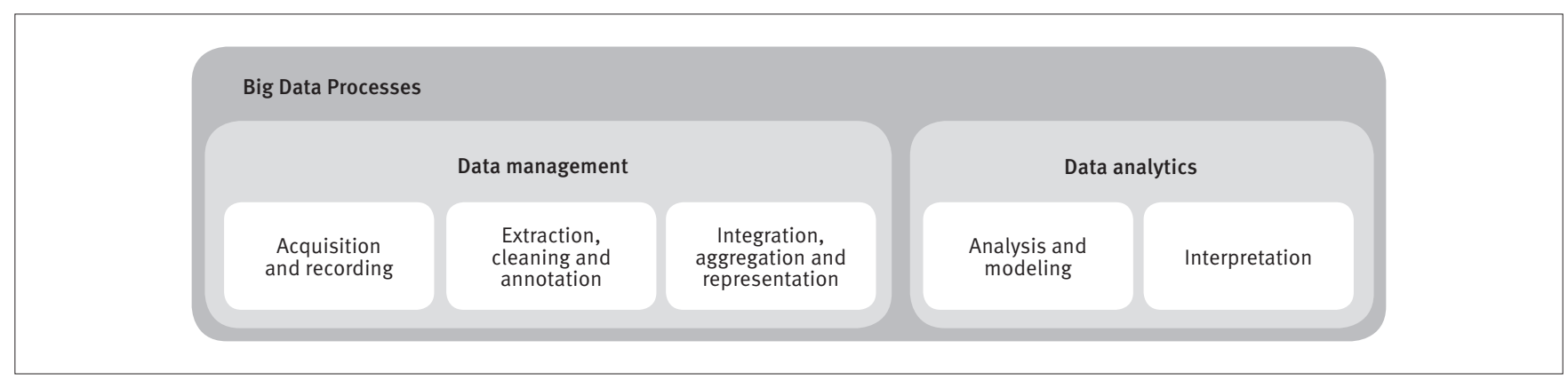

As Figure 1 shows, companies' use of BDA involves two major processes: data management and data analytics. While data management raises questions of engineering, data analytics speaks more directly to our interests as marketers. BDA is the process of getting value from data by finding hidden patterns that support data-driven decision making.

Companies considering BDA adoption face several barriers such as lack of knowledge, fear, resistance to change, and the technology's own limitations (Yaqoob et al., 2016). However, BDA improves their decision-making, utilizing techniques and software that are free and open source. This leads us to ask two questions. First, what affects its adoption? Second, why are there many companies that do not use BDA yet? Most of the literature on BDA focuses on technical aspects related to its ecosystem: application development, data mining, analytics, prediction, prescription, or statistical modeling (Sivarajah et al., 2016). There is little research about BDA adoption inside companies (Kwon, Lee, \& Shin, 2014; Brünink, 2016; Rahman, 2016; Demoulin \& Coussement, 2018; Huang, Liu, \& Chang, 2012; Verma, Bhattacharyya, \& Kumar, 2018). This study, based on the unified theory of acceptance and use of technology (UTAUT) model (Venkatesh, Morris, Davis, \& Davis, 2003), considers the impact of two new variables, resistance to use and perceived risk, on the adoption of BDA. The aim of this study is to explain the adoption and use of this new technology by companies and to understand implementation problems in order to give recommendations to practitioners. This is why we differentiate between user and non-user companies of this technology and look for different factors that affect its acceptance and use.

The second section of the paper describes the theoretical foundations of the proposed model. The third section describes the methodology we use. The fourth section analyzes the results 
FORUM | FACTORS AFFECTING THE ADOPTION OF BIG DATA ANALYTICS IN COMPANIES

Juan-Pedro Cabrera-Sánchez | Ángel F. Villarejo-Ramos

obtained from the application of the model to a sample of companies. Finally, we present the main theoretical and practical conclusions, as well as the limitations, of our research.

\section{THEORETICAL BACKGROUND AND HYPOTHESES OF THE PROPOSED MODEL}

\section{Big Data analytics and marketing}

Big Data has revolutionized marketing analytics and marketing in general. It has provided new concepts and new ways of doing things (Watson, 2019; Wedel \& Kannan, 2016) to generate a competitive advantage. BDA enables service innovation that creates strategic value for companies (Chiang, Grover, Liang, \& Zhang, 2018).

Currently, BDA is being used for marketing campaigns oriented toward increasing customer engagement (Liu, Shin, \& Burns, 2019). The literature review shows an increasing number of publications on the use of Big Data techniques aimed at creating relational marketing benefits. (Amado, Cortez, Rita, \& Moro, 2018).

Marketing management can use the huge amount of data available (for example, in social media) to gain valuable insights from their customers. Companies that exploit Big Data from social media gain competitive advantages because they know customers better (Ducange, Pecori, \& Mezzina, 2018). Studies show that, using BDA for business intelligence (Sun, Sun, \& Strang, 2018) and to maintain customer privacy (Palmatier \& Martin, 2019) creates important assets in relationship marketing.

However, the literature of BDA adoption is relatively sparse, and it is focused on the industry level (Rehman, Chang, Batool, \& Wah, 2016; Wright, Robin, Stone, \& Aravopoulou, 2019; Yadegaridehkordi et al., 2018; Lai, Sun, \& Ren, 2017). Few authors have researched which factors affect BDA adoption in companies.

\section{Acceptance models of Big Data analytics}

Technology adoption by companies and consumers is critical for success. Numerous models of technology adoption have been developed and tested, including the theory of planned behavior (TPB) (Ajzen, 1991) and the technology adoption model (TAM) (Davis, 1985). But, without doubt, the UTAUT model (Venkatesh et al., 2003) is the most comprehensive model. This model integrates previous models and theories in order to analyze technology adoption and acceptance.

Previous studies of BDA adoption in companies (Kwon et al., 2014; Brünink, 2016; Rahman, 2016; Demoulin \&
Coussement, 2018; Huang et al., 2012; Verma et al., 2018) have used the original TAM (Davis, 1985), TAM2 (Venkatesh \& Davis, 2000), TAM3 (Venkatesh \& Bala, 2008), or the UTAUT model without any added variables. Acceptance models have been upgraded since their introduction and have even evolved into new models. Because the UTAUT model is already a mature model, we enhance it with two new variables (discovered to be significant in this research), which help explain whether companies choose to adopt BDA.

The behavioral reasoning theory (Claudy, Garcia, \& O’Driscoll, 2015) provides a framework in which user involvement is very important for successful technology adoption (Ives \& Olson, 2008). Users who are predisposed to change have less resistance to adopting a new technology (Laumer, Maier, Eckhardt, \& Weitzel, 2016). Different attitudes shape the adoption process of a new technology (Gargallo López, Suárez Rodríguez, \& Almerich Cerveró, 2006). This research led us to search for different patterns among users or non-users in our sample of companies.

Our proposed model includes four independent variables drawn from the UTAUT model. First, performance expectancy is defined as the degree to which the use of technology is expected to offer benefits for the company. Second, effort expectancy measures the ease of use expected for a technology. Third, social influence measures how individuals perceive that friends and family think that they should use a technology. Fourth, facilitating conditions is defined as the extent to which consumers perceive that resources and support will be available to develop a behavior. The model proposes a direct influence of the first three variables on behavioral intention, while facilitating conditions affects behavioral intention and usage behavior. Arenas-Gaitán, PeralPeral, and Villarejo-Ramos (2016) indicate that the value of this model is its capacity to identify which factors are the main determinants of adoption. The model allows the inclusion of different moderating variables that affect the influence of the model's key constructs.

We add resistance to use and perceived risk to the UTAUT constructs. Resistance to use consists of negative reactions to change or new system implementation (Kim \& Kankanhalli, 2009). Perceived risk is the potential for losses as a result of the implementation of a new technology or information system (Featherman \& Pavlou, 2003).

\section{Hypotheses of the proposed model}

We propose several hypotheses based on the extended UTAUT model for the acceptance and use of BDA in companies. 
Performance expectancy refers to the perception of the performance that the technology is going to have and is one of the most influential constructs regarding behavioral intention. Several studies (Brünink, 2016; Chauhan \& Jaiswal, 2016; Yu, 2012) besides the original work (Venkatesh et al., 2003) support this positive relationship. Therefore, we propose as a hypothesis:

H1: Performance Expectancy positively influences the behavioral intention to use BDA.

Effort expectancy refers to the ease of learning and use of this new technology. According to the UTAUT model, the degree to which BDA will be adopted depends on the ease or difficulty of its use. Several studies find support for this relationship (Al-Gahtani, Hubona, \& Wang, 2007; Chauhan \& Jaiswal, 2016; Kim, Chan, \& Gupta, 2007; Lee \& Song, 2013; Yu, 2012) and confirm the effect of effort expectancy on behavioral intention. Thus, we offer as a second hypothesis of the model:

$\mathrm{H}_{2}$ : Effort Expectancy, or ease of use, positively affects the behavioral intention to use BDA.

The concept of social influence developed in the original work of Venkatesh et al. (2003) and extended in UTAUT2 (Venkatesh, Thong, \& Xu, 2012) measures the effect of what others (friends and family) think about this technology. In a professional environment, what managers and colleagues think is also very important (Al-Gahtani et al., 2007; Brünink, 2016; Chauhan \& Jaiswal, 2016; Gupta, Huang, \& Niranjan, 2010; H. W. Kim et al., 2007; Lee \& Song, 2013). Therefore, we propose as a hypothesis:

H3: Social Influence positively affects the behavioral intention to Use BDA.

Resistance to use consists of opposition or negative reactions to the implementation of a new technology. As Gibson (2004) finds, the introduction of many new technologies have failed due to the opposition of users to their implementation. Although current literature recognizes resistance to use (Kim \& Kankanhalli, 2009; Lapointe \& Rivard, 2007), there are few studies that integrate it into the UTAUT model. Nevertheless, there are precedents for using it to explain behavioral intention (Hsieh, 2015). Norzaidi, Salwani, Chong, and Rafidah (2008) verify the relationship between user resistance and usage, a finding confirmed by other studies that do not use the UTAUT model (Bhattacherjee \& Hikmet, 2007; Poon et al., 2000). Therefore, we offer as a hypothesis:

$\mathrm{H}_{4}$ : Resistance Use negatively affects behavioral intention to use BDA.
Perceived risk consists of the potential for losses in the implementation of a new technology. In addition to the work of Featherman and Pavlou (2003) which includes the measurement scale that we use, many studies about perceived risk as a negative antecedent of behavioral intention (Kim, Ferrin, \& Rao, 2008; Lee \& Song, 2013; Martins, Oliveira, \& Popovič, 2014). Therefore, we propose as a hypothesis:

$\mathrm{H}_{5}$ : Perceived Risk negatively affects behavioral intention to use BDA.

Facilitating conditions are favorable when there is easy access to the resources needed to use a new technology and to subsequent support (Venkatesh et al., 2003). In later studies using UTAUT2, Venkatesh et al. (2012) found that this construct has a significant effect on the behavioral intention to use a new technology. Also, more recent studies have verified this positive effect on behavioral intention (Duyck et al., 2010; Hung, Wang, Cho, \& Chou, 2007; Wu, Tao, \& Yang, 2007). Thus, we offer as a hypothesis:

H6: Facilitating Conditions positively influence the behavioral intention to use BDA.

Both TPB (Ajzen, 1991) and UTAUT (Venkatesh et al., 2003) have been used to show how favorable facilitating conditions positively affect the use of a new technology. Various subsequent works (Al-Gahtani et al., 2007; Brünink, 2016; Chauhan \& Jaiswal, 2016; Duyck et al., 2010; Kim et al., 2007) also support this relationship. Therefore, we propose as a hypothesis:

$\mathrm{H}_{7}$ : Facilitating Conditions positively affect the use of BDA.

The main technology acceptance models (TRA, TAM, UTAUT, and UTAUT2) show a direct relationship between behavioral intention and the use of technologies (Fishbain \& Ajzen, 1975; Davis, 1985; Venkatesh et al., 2003; 2012). This influence has been demonstrated in contexts similar to the adoption of BDA, such as internet banking (Martins et al., 2014), online flight purchasing (Escobar-Rodríguez \& Carvajal-Trujillo, 2014), electronic document management systems (Afonso, Gonzalez, Roldán, \& Sánchez-Franco, 2012) and ERP (Enterprise Resource Planning) (Chauhan \& Jaiswal, 2016). Therefore, we can enunciate as a hypothesis:

H8: The behavioral intention to use BDA positively affects its use.

In Figure 2, we show the proposed model of the acceptance and use of BDA with pathways identified in our hypotheses. 
Figure 2. Big Data Acceptance model in companies

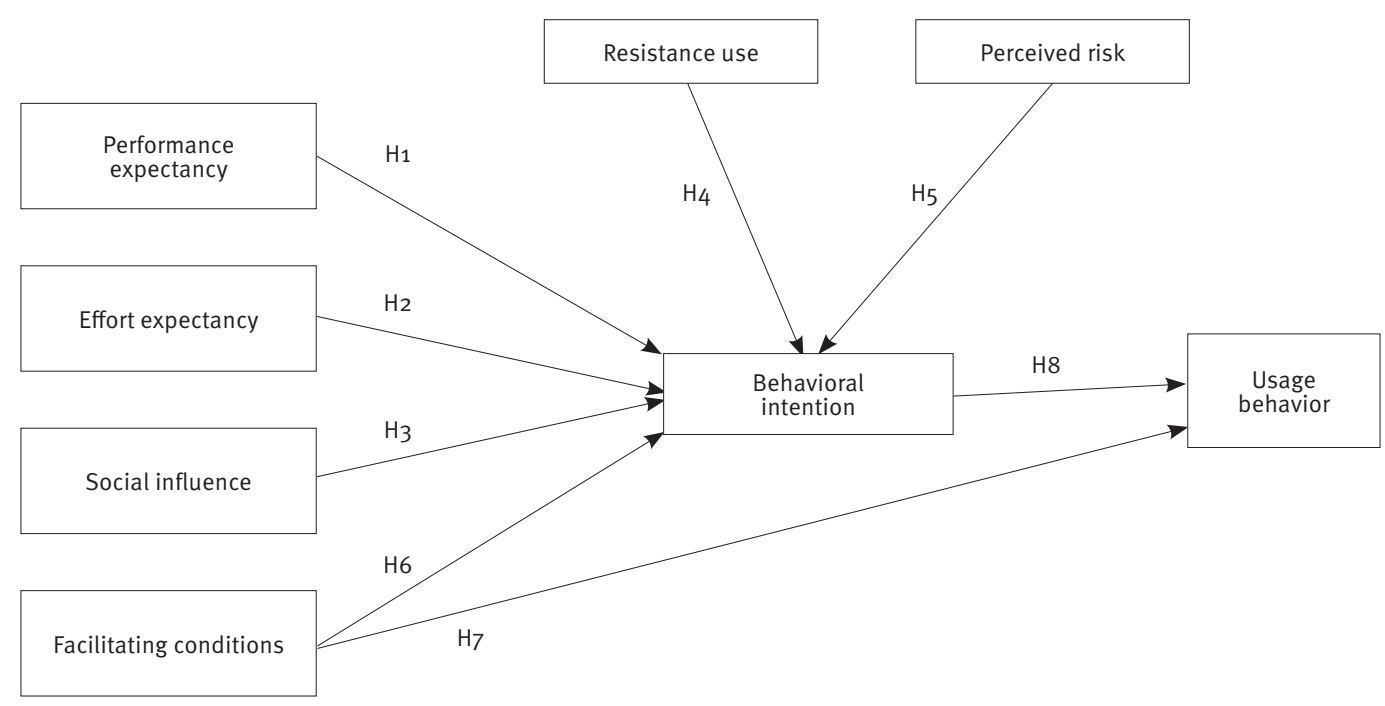

\section{RESEARCH METHODOLOGY}

\section{Sample description}

Our survey, collected between September and October of 2017 via personal emails and phone, sampled 199 responses of company CEOs and managers of different areas, such as human resources, finance, marketing, and sales. A pre-test of the survey was carried out with five volunteer managers and several expert researchers, who completed the questionnaire and provided feedback about the questions. In Table 1, we classify the companies of the respondents according to their revenues and sectors.

Table 1. Companies of the sample according to revenue and activity sector

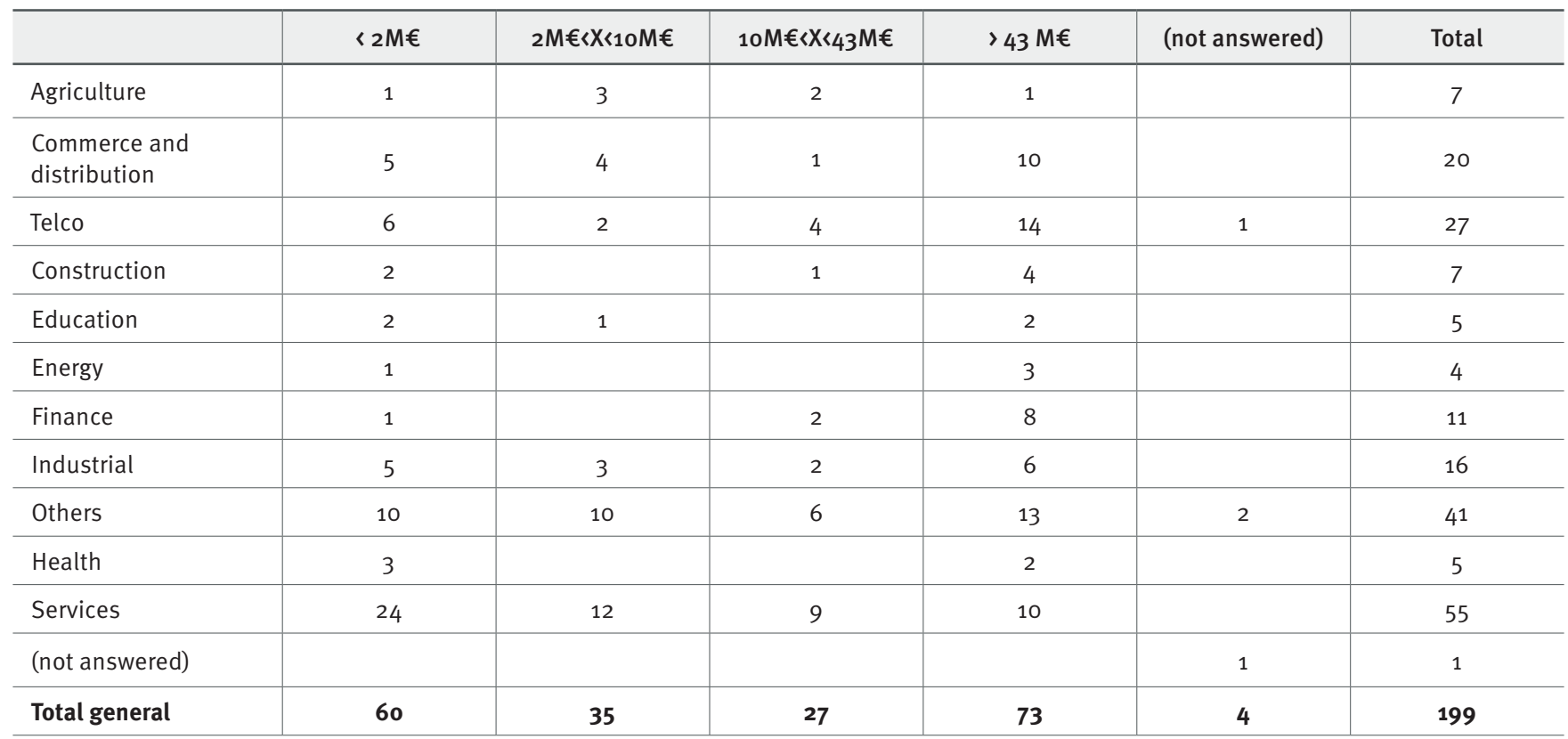




\section{Measurement scales}

For the UTAUT constructs, we adapt scales from Venkatesh et al. (2003) to BDA. Resistance to use was measured with the scale proposed by Bhattacherjee and Hikmet (2007), while perceived risk was measured with the scale from Featherman and Pavlou (2003). Seven point Likert scales were used in all cases.

\section{Statistical tools}

To estimate the structural model, we used partial least squares (PLS), (Chin \& Dibbern, 2010; Hair et al., 2012) with the statistical software Smart PLS 3.2.3 (Ringle, Wende, \& Becker, 2015). To avoid measurement bias, or common method bias (CMB), in the observed sample, we followed the recommendations of BurtonJones (2009). We have also follow Podsakoff, MacKenzie, Lee, \& Podsakoff (2003), MacKenzie, Podsakoff, \& Podsakoff (2011); Podsakoff, MacKenzie, \& Podsakoff (2012), and Kock \& Lynn (2012). Because the study focuses on CMB and PLS for structural equation models. We follow Kock (2015) and add unrelated questions in order to create a new latent variable with these indicators and the other variables as antecedents. This CMB variable acts as the dependent variable for all of the others in the model. The variance inflation factors estimated by this method must be lower than 3.3 to confirm that the sample does not have CMB. In Table 2, we show that our sample complies with this requirement.

Table 2. VIF from all variables to check CMB

\begin{tabular}{l|c}
\hline & Variable_CMB \\
\hline Behavioral intention & 2.423 \\
\hline Effort expectancy & 1.631 \\
\hline Facilitating conditions & 2.472 \\
\hline Perceived risk & 1.288 \\
\hline Performance expectancy & 1.994 \\
\hline Resistance to use & 1.852 \\
\hline Social influence & 1.675 \\
\hline Usage behavior & 1.996 \\
\hline
\end{tabular}

\section{RESULTS}

We checked the reliability of all of the constructs. Current literature suggests that for measurement models to be considered reliable and valid, each factor loading should exceed 0.7 (Roldán \& Sánchez-Franco, 2012; Henseler, Ringle, \& Sarstedt, 2014). In Table 3, we show that each loadings was over 0.7, except for the third indicator for facilitating conditions (FC3), which was dropped.

\section{Table 3. Reliability of measurement scales (loadings)}

\begin{tabular}{|c|c|c|c|c|c|c|c|c|}
\hline & $\begin{array}{l}\text { Behavioral } \\
\text { intention }\end{array}$ & $\begin{array}{c}\text { Effort } \\
\text { expectancy }\end{array}$ & $\begin{array}{l}\text { Facilitating } \\
\text { conditions }\end{array}$ & $\begin{array}{l}\text { Perceived } \\
\text { risk }\end{array}$ & $\begin{array}{l}\text { Performance } \\
\text { expectancy }\end{array}$ & $\begin{array}{l}\text { Resistance } \\
\text { to use }\end{array}$ & $\begin{array}{c}\text { Social } \\
\text { influence }\end{array}$ & $\begin{array}{l}\text { Usage } \\
\text { behavior }\end{array}$ \\
\hline $\mathrm{Bl} 1$ & 0.970 & & & & & & & \\
\hline $\mathrm{Bl} 3$ & 0.984 & & & & & & & \\
\hline $\mathrm{Bl} 4$ & 0.974 & & & & & & & \\
\hline EE2 & & 0.887 & & & & & & \\
\hline $\mathrm{EE}_{3}$ & & 0.898 & & & & & & \\
\hline $\mathrm{EE}_{4}$ & & 0.874 & & & & & & \\
\hline $\mathrm{FC}_{4}$ & & & 0.847 & & & & & \\
\hline $\mathrm{PR} 1$ & & & & 0.927 & & & & \\
\hline
\end{tabular}


Table 3. Reliability of measurement scales (loadings)

Conclusion

\begin{tabular}{|c|c|c|c|c|c|c|c|c|}
\hline & $\begin{array}{l}\text { Behavioral } \\
\text { intention }\end{array}$ & $\begin{array}{c}\text { Effort } \\
\text { expectancy }\end{array}$ & $\begin{array}{l}\text { Facilitating } \\
\text { conditions }\end{array}$ & $\begin{array}{l}\text { Perceived } \\
\text { risk }\end{array}$ & $\begin{array}{l}\text { Performance } \\
\text { expectancy }\end{array}$ & $\begin{array}{l}\text { Resistance } \\
\text { to use }\end{array}$ & $\begin{array}{c}\text { Social } \\
\text { influence }\end{array}$ & $\begin{array}{c}\text { Usage } \\
\text { behavior }\end{array}$ \\
\hline PR2 & & & & 0.924 & & & & \\
\hline$P E_{1}$ & & & & & 0.899 & & & \\
\hline PE4 & & & & & 0.918 & & & \\
\hline $\mathrm{PE}_{5}$ & & & & & 0.785 & & & \\
\hline PE6 & & & & & 0.829 & & & \\
\hline $\mathrm{RU}_{3}$ & & & & & & 0.938 & & \\
\hline $\mathrm{RU}_{4}$ & & & & & & 0.902 & & \\
\hline $\mathrm{Sl} 1$ & & & & & & & 0.741 & \\
\hline $\mathrm{Sl} 2$ & & & & & & & 0.877 & \\
\hline $\mathrm{Sl}_{3}$ & & & & & & & 0.817 & \\
\hline $\mathrm{SI}_{4}$ & & & & & & & 0.792 & \\
\hline $\mathrm{Sl}_{5}$ & & & & & & & 0.724 & \\
\hline
\end{tabular}

Next, we analyzed construct reliability using composite reliability indicators and Cronbach's Alpha. In all cases, the values of our indicators were above 0.7 as suggested by Nunnally (1978). We assured convergent validity by analyzing the average variance extracted. All of the values were above the 0.5 threshold proposed by Straub, Detmar, Boudreau, and Gefen (2004). These indicators, shown in Table 4, meet the requirements.

Table 4. Composite reliability and Convergent validity

\begin{tabular}{|c|c|c|c|c|}
\hline & Cronbach's Alpha & rho_A & $\begin{array}{c}\text { Composite } \\
\text { reliability }\end{array}$ & $\begin{array}{c}\text { Average } \\
\text { Variance Extracted } \\
\text { (AVE) }\end{array}$ \\
\hline Effort expectancy & 0.906 & 0.934 & 0.928 & 0.722 \\
\hline Perceived risk & 0.896 & 0.909 & 0.935 & 0.828 \\
\hline Performance expectancy & 0.940 & 0.947 & 0.951 & 0.736 \\
\hline Resistance to use & 0.951 & 0.954 & 0.965 & 0.872 \\
\hline Social influence & 0.851 & 0.874 & 0.893 & 0.627 \\
\hline
\end{tabular}


Next, we evaluated the discriminant validity of the measurement model in two ways. First, we conducted Fornell and Larcker's test (Barclay, Higgins, \& Thompson, 1995). Second, using the Heterotrait-Monotrait (HTMT) ratio (Henseler et al., 2014), we ensured that in all cases all of the values were below 0.9. The results of both tests are shown in Tables 5 and 6.

Table 5. Discriminant validity (Fornell-Larcker's test)

\begin{tabular}{|c|c|c|c|c|c|c|c|c|}
\hline & $\begin{array}{l}\text { Behavioral } \\
\text { intention }\end{array}$ & $\begin{array}{c}\text { Effort } \\
\text { expectancy }\end{array}$ & $\begin{array}{l}\text { Facilitating } \\
\text { conditions }\end{array}$ & $\begin{array}{l}\text { Perceived } \\
\text { risk }\end{array}$ & $\begin{array}{l}\text { Performance } \\
\text { expectancy }\end{array}$ & $\begin{array}{l}\text { Resistance } \\
\text { to use }\end{array}$ & $\begin{array}{c}\text { Social } \\
\text { influence }\end{array}$ & $\begin{array}{l}\text { Usage } \\
\text { behavior }\end{array}$ \\
\hline Behavioral intention & 0.979 & & & & & & & \\
\hline Effort expectancy & 0.384 & 0.850 & & & & & & \\
\hline Perceived risk & -0.331 & -0.185 & -0.283 & 0.910 & & & & \\
\hline Performance expectancy & 0.544 & 0.434 & 0.373 & -0.195 & 0.858 & & & \\
\hline Resistance to use & -0.506 & -0.258 & -0.343 & 0.408 & -0.566 & 0.934 & & \\
\hline
\end{tabular}

Table 6. Discriminant validity (Ratio Heterotrait-Monotrait -HTMT)

\begin{tabular}{|c|c|c|c|c|c|c|c|c|}
\hline & $\begin{array}{l}\text { Behavioral } \\
\text { intention }\end{array}$ & $\begin{array}{c}\text { Effort } \\
\text { expectancy }\end{array}$ & $\begin{array}{l}\text { Facilitating } \\
\text { conditions }\end{array}$ & $\begin{array}{c}\text { Perceived } \\
\text { risk }\end{array}$ & $\begin{array}{l}\text { Performance } \\
\text { expectancy }\end{array}$ & $\begin{array}{c}\text { Resistance } \\
\text { to use }\end{array}$ & $\begin{array}{c}\text { Social } \\
\text { influence }\end{array}$ & $\begin{array}{l}\text { Usage } \\
\text { behavior }\end{array}$ \\
\hline \multicolumn{9}{|l|}{ Behavioral intention } \\
\hline Effort expectancy & 0.380 & & & & & & & \\
\hline Facilitating conditions & 0.690 & 0.649 & & & & & & \\
\hline Perceived risk & 0.349 & 0.202 & 0.324 & & & & & \\
\hline Performance expectancy & 0.559 & 0.449 & 0.411 & 0.206 & & & & \\
\hline Resistance to use & 0.521 & 0.269 & 0.383 & 0.443 & 0.597 & & & \\
\hline Social influence & 0.532 & 0.507 & 0.567 & 0.297 & 0.524 & 0.254 & & \\
\hline Usage behavior & 0.635 & 0.355 & 0.679 & 0.287 & 0.405 & 0.408 & 0.476 & \\
\hline
\end{tabular}

The values of $\mathrm{R}^{2}$ for the second order constructs (behavioral intention and usage behavior) are shown in Table 7.

Table $7 \cdot \mathbf{R}^{2}$ of the model

\begin{tabular}{l|c|c}
\hline & R squared & $\begin{array}{c}\text { Adjusted } \\
\text { R squared }\end{array}$ \\
\hline Behavioral intention & 0.560 & 0.546 \\
\hline Usage behavior & 0.483 & 0.478 \\
\hline
\end{tabular}


Figure 3 shows the values for every loading and path of the model.

Figure 3. Results of the model

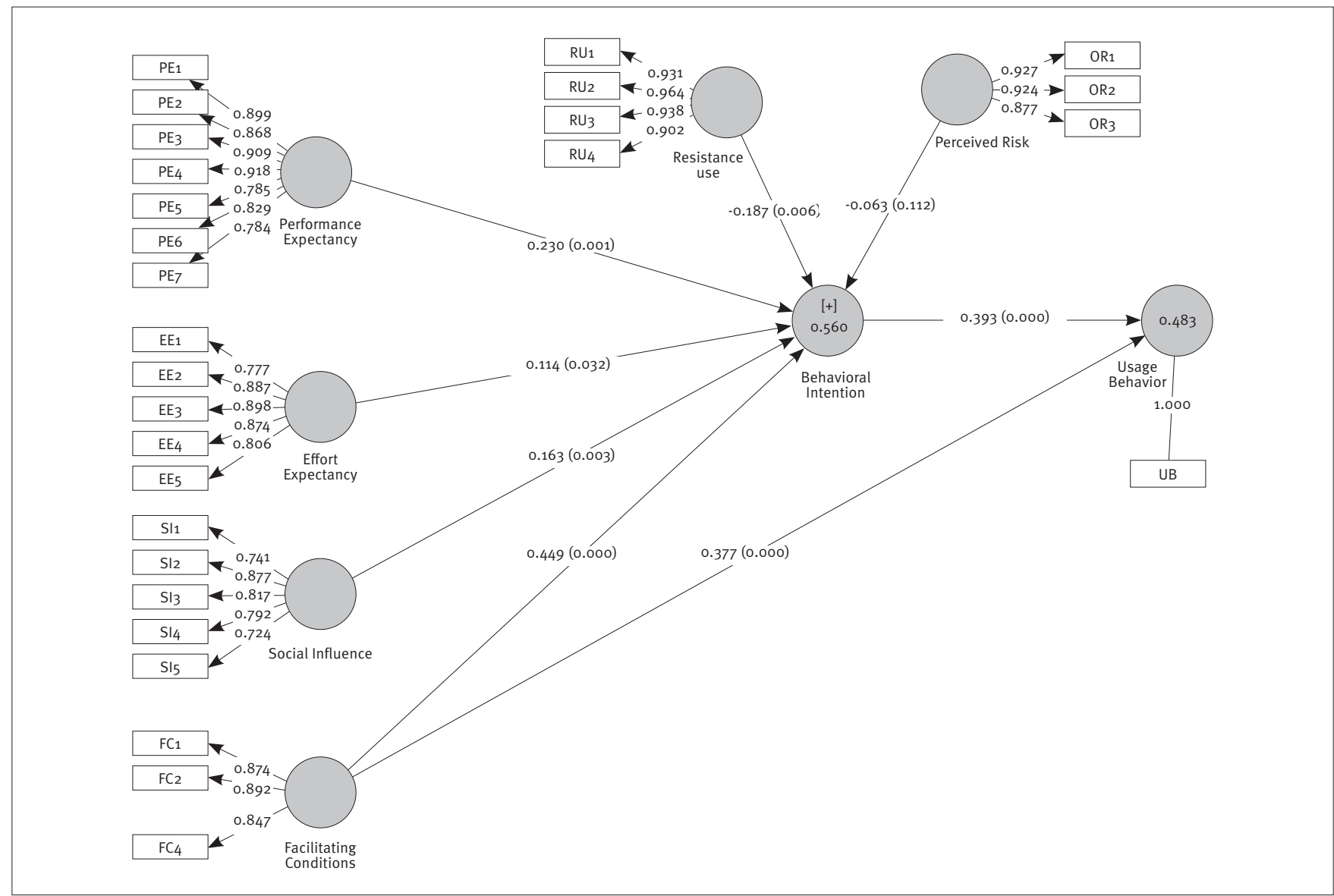

To evaluate the structural model, we analyzed the values of the path coefficients and the explained variance of the endogenous variables $\left(R^{2}\right)$. The path coefficients show the intensity of the relationship between the independent and dependent variables. We used a bootstrapping technique with 5,000 samples to find the reliability of the estimated path coefficients, as shown in Table 8 .

Table 8. Structural model estimates (Path coefficients)

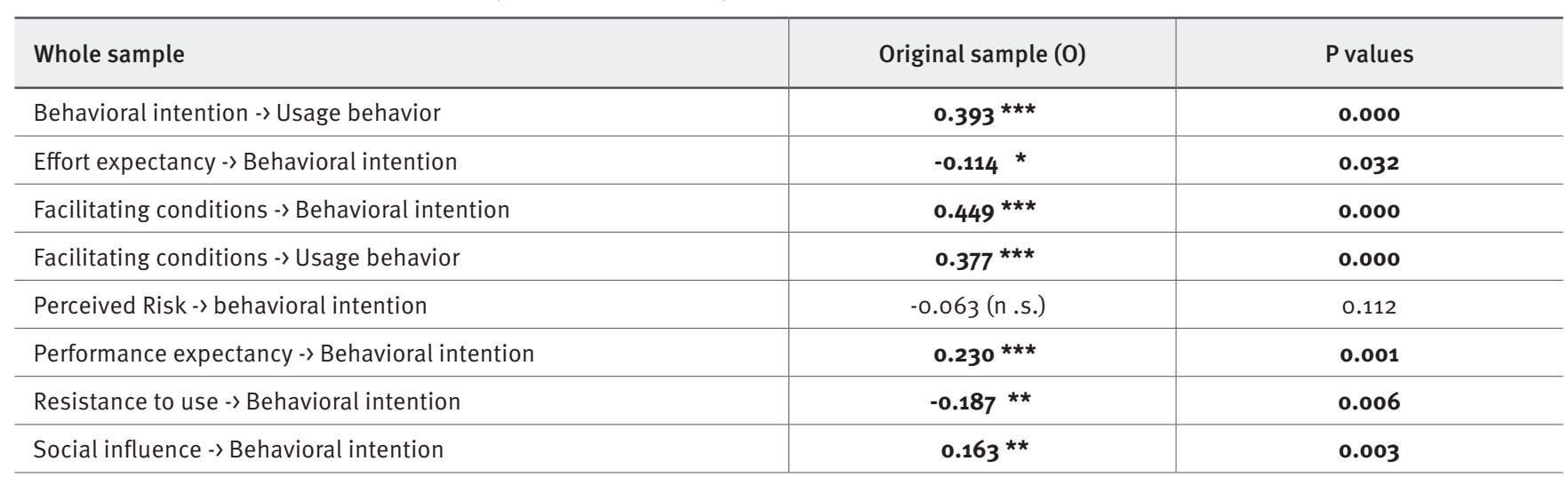

***p<0.001, **p<0.01, *p<0.05. (bootstrapping with 5,000 sub-samples and 1-tailed test).

Significant relationships with path coefficients and $p$ value in bold. 
We calculated the SRMR (Standardized Root Mean-square Residual) indicator to assess model fit. The value obtained, 0.065 , was less than the 0.08 threshold proposed by Henseler et al. (2014), which suggests a good fit for the model. The model explains $47.85 \%$ of the variation in usage and $54.6 \%$ of the variation in behavioral intention (see Table 7), both of which exceed the minimum level of $10 \%$ recommended by Falk and Miller (1992).

The results support most of the hypotheses, except for $\mathrm{H}_{5}$ (perceived risk) and $\mathrm{H}_{2}$ (effort expectancy). The coefficients for supported hypothesis are significant at the $1 \%$ level. Although effort expectancy is significant at the $5 \%$ level, we have found a negative relationship that is due to a suppressor effect (Falk \& Miller, 1992) produced by the new relationship facilitating conditions on behavioral intention so we can reject $\mathrm{H}_{2}$. In order of influence, we can see that facilitating conditions contributes most to behavioral intention and the second most to usage. The second contributor to behavioral intention is performance expectancy while the first contributor to usage is behavioral intention. We also note that the coefficient for behavioral intention on usage is significant at the $0.1 \%$ level. The coefficient for the effect of resistance to use on behavioral intention is significant and negative.

We also calculated the Stone-Geisser $\mathrm{Q}^{2}$ to evaluate the predictive capacity of the model (Gefen, Rigdon, \& Straub, 2011). The results are shown in Table 9.

\section{Table 9. Prediction of latent variables}

\begin{tabular}{l|l|l}
\hline & RMSE & Q2 \\
\hline Behavioral intention & 0.558 & 0.502 \\
\hline Usage behavior & 0.522 & 0.397 \\
\hline
\end{tabular}

We conclude that the model has predictive relevance as the values of $\mathrm{Q}^{2}$ in Table 9 are greater than zero (Roldán \& SánchezFranco, 2012).

We considered the possibility of heterogeneity in the sample. Following Becker, Rai, Ringle, and Völckner (2013), we ran a PLS-POS latent class segmentation and also a FIMIX latent class segmentation. We find no differences in groups with a posteriori segmentation.

Next, we tried several a priori segmentations with different criteria (e.g., company size, use of Big Data, activity sector, finding no differences between these sub-samples. However, we did find different behaviors in companies when we asked about the maturity level of the implementation of BDA. We used the scale proposed by Paulk, Curtis, Chrissis and Weber (1993), which has been widely used (Berg, Leinonen, Leivo, \& Pihlajamaa, 2002; Khatibian, Hasan, \& Jafari, 2010; Urwiler \& Frolick, 2008) and has five levels: initial, repeatable, defined, managed, and optimizing. We assigned companies that had not implemented BDA or were in the first two levels to Segment 1 and those in the last three levels to Segment 2. As shown in Table 10 for Segment 1 and in Table 11 for Segment 2, there are significant differences between these two segments and the whole sample (see Table 8).

\section{Table 10. Segment 1. Structural Model Estimates (Path Coefficients)}

\begin{tabular}{|c|c|c|}
\hline $\begin{array}{l}\text { NON-USERS and } \\
\text { BEGINERS } \\
\text { Segment 1. Size: } 152 \\
\text { companies }\end{array}$ & Original sample (0) & $P$ values \\
\hline $\begin{array}{l}\text { Behavioral intention -> } \\
\text { Usage behavior }\end{array}$ & $0.387^{* * *}$ & 0.000 \\
\hline $\begin{array}{l}\text { Effort expectancy -> } \\
\text { Behavioral intention }\end{array}$ & -0.092 (n. s.) & 0.094 \\
\hline $\begin{array}{l}\text { Facilitating conditions } \\
\text {-> Behavioral intention }\end{array}$ & $0.344^{* * *}$ & 0.000 \\
\hline $\begin{array}{l}\text { Facilitating conditions } \\
\text {-> Usage behavior }\end{array}$ & 0.237 ** & 0.002 \\
\hline $\begin{array}{l}\text { Perceived risk -> } \\
\text { Behavioral intention }\end{array}$ & -0.073 (n. s.) & 0.106 \\
\hline $\begin{array}{l}\text { Performance } \\
\text { expectancy -> } \\
\text { Behavioral intention }\end{array}$ & $0.330 * * *$ & 0.000 \\
\hline $\begin{array}{l}\text { Resistance to use -> } \\
\text { Behavioral intention }\end{array}$ & -0.227 ** & 0.002 \\
\hline $\begin{array}{l}\text { Social influence -> } \\
\text { Behavioral intention }\end{array}$ & 0.189 ** & 0.002 \\
\hline
\end{tabular}

${ }^{* * *}$ p $<0.001,{ }^{* *}$ p $<0.01,{ }^{*}$ p $<0.05$. (bootstrapping with 5,000 sub-samples and 1-tailed test) Significant relationships with path coefficients and $p$ value in bold. 


\section{Table 11. Segment 2. Structural model estimates (Path coefficients)}

\begin{tabular}{l|c|c}
\hline $\begin{array}{l}\text { USERS and HEAVY USERS } \\
\text { Segment 2. Size: } 47 \\
\text { companies }\end{array}$ & $\begin{array}{c}\text { Original sample } \\
(\mathbf{0})\end{array}$ & P values \\
\hline $\begin{array}{l}\text { Behavioral intention -> } \\
\text { Usage behavior }\end{array}$ & $\mathbf{0 . 5 6 1 * * *}$ & $\mathbf{0 . 0 0 1}$ \\
\hline $\begin{array}{l}\text { Effort expectancy -> } \\
\text { Behavioral intention }\end{array}$ & -0.186 (n. s.) & 0.084 \\
\hline $\begin{array}{l}\text { Facilitating conditions -> } \\
\text { Behavioral intention }\end{array}$ & $\mathbf{0 . 6 4 8}$ *** & $\mathbf{0 . 0 0 1}$ \\
\hline $\begin{array}{l}\text { Facilitating conditions -> } \\
\text { Usage behavior }\end{array}$ & 0.128 (n .s.) & 0.188 \\
\hline $\begin{array}{l}\text { Perceived risk -> } \\
\text { Behavioral intention }\end{array}$ & -0.188 (n. s.) & 0.106 \\
\hline $\begin{array}{l}\text { Performance expectancy } \\
->\text { Behavioral intention }\end{array}$ & -0.214 (n. s.) & 0.174 \\
\hline $\begin{array}{l}\text { Resistance to use -> } \\
\text { Behavioral intention }\end{array}$ & -0.207 (n. s.) & 0.172 \\
\hline $\begin{array}{l}\text { Social influence -> } \\
\text { Behavioral intention }\end{array}$ & 0.056 (n. s.) & 0.354 \\
\hline
\end{tabular}

${ }^{* * *}$ p $<0.001,{ }^{* *}$ p $<0.01,{ }^{*} p<0.05$. (bootstrapping with 5,000 sub-samples and 1 -tailed test). Significant relationships with path coefficients and $p$ value in bold.

We performed an ANOVA test and confirmed the significant differences between the sub-samples. For companies that were non-users or beginners (Segment 1), all relationships were significant except for the effects of perceived risk and effort expectancy on behavioral intention. Facilitating conditions and performance expectancy were the strongest contributors to behavioral intention with high levels of significance. The coefficients for resistance to use and social influence were also large and significant. For users and heavy users (Segment 2), none of the relationships was significant except the effect of facilitating conditions on behavioral intention. It had the strongest effect of all the relationships in this study. Curiously, performance expectancy was not significant.

\section{DISCUSSION, CONCLUSIONS AND LIMITATIONS}

Our research extends the UTAUT model for Big Data with a new variable, resistance to use. With this extension, we contribute to the generalization of the model and to a better understanding of technology acceptance. Our model adds to previous research on BDA by including a new independent variable, resistance to use, to the UTAUT model and including usage behavior of BDA as an outcome variable. Brünink (2016) uses the UTAUT model without adding resistance to use or explaining actual usage behavior. Other studies (Demoulin \& Coussement, 2018) focus on management support for the use of Big Data applications, using models such as TAM, TAM2, or TAM3 (Brown \& Venkatesh, 2005; Huang et al., 2012; Verma et al., 2018) These models explain the adoption and actual use of BDA in companies, but are more limited than the UTAUT model.

Our results show that the behavioral intention to use BDA in companies is determined by four factors. First, performance expectancy, the perception that implementation of this technology will achieve good results, increases adoption, as shown in previous studies (Lee \& Song, 2013; Yu, 2012). Second, social influence has a positive effect on the intention to use BDA, as demonstrated in previous papers (Bozan, Parker, \& Davey, 2016). Third, facilitating conditions, company provision of support and necessary resources for usage, increases both behavioral intention and usage (Alharbi, 2014). Finally, resistance to use decreases behavioral intentions to use BDA in companies, with a stronger effect than social influence.

We also find that although the use of BDA is perceived to be difficult (effort expectancy), the influence of this perception on behavioral intention is small and contained into other relationship: facilitation conditions on behavioral intention (suppressor effect abovementioned).

We also find a positive effect of facilitating conditions on the usage behavior of the new technology with a similar loading for behavioral intention. Thus, we can say that the findings are consistent with all of the hypotheses of the UTAUT model, except for $\mathrm{H}_{5}$ (perceived risk). Because we find it has a significant effect, we propose adding resistance to use to the original model, in order to improve explanations of the acceptance and use of BDA in companies.

Finally, we highlight the differences in behavior between companies that are not using these techniques or are beginning to use them (Segment 1) and the companies that have already been using them for a long time (Segment 2). For the beginners or nonuser companies, performance expectancy, social influence, and facilitating conditions have strong positive effects on behavioral intention and usage behavior, while resistance to use has a strong negative effect on both variables. Among user and heavy user companies, only facilitating conditions has an effect on behavioral intention, while the rest of relationships are not significant. This may suggest that established users know what they can achieve with these techniques so the only thing they care is about having good facilitating conditions while beginners still do not know 
all the capabilities of this technology so they take into account more issues.

As to professional implications, the results suggest that executives assume that every technology has its own learning curve, and this issue does not affect its adoption whenever great results are expected, as in the case of Big Data (CabreraSánchez \& Villarejo-Ramos, 2018). Likewise, if the company has the appropriate infrastructure, it does not lose anything if it tests the technology. In any case, overcoming the resistance to use it still requires clear information about its benefits. Therefore, we recommend two steps for managers. First, they should be informed that most software associated with these techniques is free and that if they already have hardware resources, they should test it. Second, there should be communication with managers about the benefits of using Big Data, including examples of companies using it in the same areas. This second action is very important for companies who are currently using Big Data because we can infer that they are not squeezing all of the potential from the technology. They are somewhat upset about the technology, and they have a very poor performance expectancy when this just the opposite should be true. Therefore, we must inform them about the technology and how it can be used to generate profits in each sector.

The use of BDA in companies can be a very important advance in information management to improve customer relationships. As it is more than a customer relationship management tool, BDA gives companies relevant information and increases customers' knowledge, improving their engagement.

Although the UTAUT model is well-tested and mature, we have included two variables to extend it. However, there may be many more variables that are relevant. For this technology, there are constructs from the original model such as performance expectancy that have a lower influence on behavioral intention than one of the constructs we added, resistance to use. Because other new variables with strong effects may exist, the UTAUT model must continue to evolve in order to provide better explanations for the acceptance of new technologies. Future research on Big Data should seek to identify these variables. Also, it seems necessary to explore new moderator variables with the aim of analyzing possible effects not previously taken into account.

Finally, larger sample sizes will allow us to establish differences in behavior between groups of companies, which we can analyze via an a posteriori segmentation technique, such as Posteriori Oriented Segmentation- Partial Least Squares (POSPLS). So, if we get a bigger sample of companies that are using (or are intending to use) Big Data, we will have a better performance of this model and more informative results.

\section{REFERENCES}

Afonso, C., Gonzalez, M., Roldán, J., \& Sánchez-Franco, M. (2012). Determinants of user acceptance of a local eGovernment Electronic Document Management System (EDMS). In Proceedings of the 12th European Conference on e-Government, ECEG (pp. 19-28), Barcelona: Academic Publishing International Limited.

Agrawal, D., Bernstein, P., \& Bertino, E. (2011). Challenges and opportunities with Big Data 2011-1. Proceedings of the VLDB Endowment (pp. 1-16). Retrieved from http://dl.acm.org/citation. cfm?id=2367572\%5Cnhttp://docs.lib.purdue.edu/cctech/1/

Ajzen, I. (1991). The theory of planned behavior. Organizational Behavior and Human Decision Processes, 50(2), 179-211. doi:10.1016/07495978(91)90020-T

Akerkar, R. (2014). Analytics on big aviation data: Turning data into insights. International Journal of Computer Science and Applications, 11(3), 116-127.

Al-Gahtani, S. S., Hubona, G. S., \& Wang, J. (2007). Information technology (IT) in Saudi Arabia: Culture and the acceptance and use of IT. Information \& Management, 44(8), 681-691. doi:10.1016/j. im.2007.09.002

Alharbi, S. T. (2014). Trust and acceptance of cloud computing: A revised UTAUT model. Proceedings - 2014 International Conference on Computational Science and Computational Intelligence, CSCl 2014 , 2(Mm) (pp. 131-134). doi:10.1109/CSCl.2014.107

Amado, A., Cortez, P., Rita, P., \& Moro, S. (2018). Research trends on Big Data in marketing: A text mining and topic modeling based literature analysis. European Research on Management and Business Economics, 24(1), 1-7. doi:10.1016/j.iedeen.2017.06.002

Arenas-Gaitán, J., Peral-Peral, B., \& Villarejo-Ramos, A.-F. (2016). Grupos de mayores en la banca electrónica. Segmentación de clases latentes con PLS-POS. In Congreso Marketing AEMARK. Madrid, Spain.

Barclay, D., Higgins, C., \& Thompson, R. (1995). The Partial Least Squares (PLS) approach to causal modelling: Personal computer adoption and use as an illustration. Technology Studies, 2(2), 285-309.

Becker, J.-M., Rai, A., Ringle, C. M., \& Völckner, F. (2013). Discovering unobserved heterogeneity in structural equation models to avert Validity threats. MIS Quarterly, 37(3), 665-694. doi:10.25300/ MISQ/2013/37.3.01

Berg, P., Leinonen, M., Leivo, V., \& Pihlajamaa, J. (2002). Assessment of quality and maturity level of R\&D. International Journal of Production Economics, 78(1), 29-35. doi:10.1016/So925-5273(00)00166-3

Bhattacherjee, A., \& Hikmet, N. (2007). Physicians' resistance toward healthcare information technology: A theoretical model and empirical test. European Journal of Information Systems, 16(6), 725 737. doi:10.1057/palgrave.ejis.3000717

Bozan, K., Parker, K., \& Davey, B. (2016). A closer look at the social influence construct in the UTAUT Model: An institutional theory based approach to investigate health IT adoption patterns of the elderly. Proceedings of the Annual Hawaii International Conference on System Sciences, 2016-March (pp. 3105-3114). doi:10.1109/ HICSS.2016.391

Brown, S. A., \& Venkatesh, V. (2005). Model of adoption of technology in households: A baseline model test and extension incorporating household life cycle. MIS Quarterly, 29(3), 399-426. doi:10.2307/25148690 
Brünink, L. (2016). Cross-functional Big Data integration: Applying the UTAUT model. University of Twente (The Netherlands).

Burton-Jones. (2009). Minimizing method bias through programmatic research. MIS Quarterly, 33(3), 445-471. doi:10.2307/20650304

Cabrera-Sánchez, J.-P., \& Villarejo-Ramos, Á.-F. (2018). Factores que afectan a la adopción del Big Data como instrumento de marketing en las empresas españolas. In XXVIII Jornadas Luso-Espanholas de Gestâo Científica, At Guarda (Portugal).

Chauhan, S., \& Jaiswal, M. (2016). Determinants of acceptance of ERP software training in business schools: Empirical investigation using UTAUT model. International Journal of Management Education, 14(3), 248-262. doi:10.1016/j.ijme.2016.05.005

Chiang, R. H. L., Grover, V., Liang, T.-P., \& Zhang, D. (2018). Special issue: strategic value of Big Data and business analytics. Journal of Management Information Systems, 35(2), 383-387. doi:10.1080/074 21222.2018.1451950

Chin, W. W., \& Dibbern, J. (2010). An introduction to a permutation based procedure for multi-group PLS analysis: Results of tests of differences on simulated data and a cross-cultural analysis of the sourcing of information system services between Germany and the USA. In V. E. Vinzi, W. W. Chin, J. Henseler, \& H. Wang (Eds.), Handbook of partial least squares (pp. 171-193). doi:10.1007/978-3-540-32827-8

Claudy, M. C., Garcia, R., \& O’Driscoll, A. (2015). Consumer resistance to innovation: A behavioral reasoning perspective. Journal of the Academy of Marketing Science, 43(4), 528-544. doi:10.1007/s11747014-0399-0

Davis, F. (1985). A technology acceptance model for empirically testing new end-user information systems. Massachusetts Institute of Technology, Sloan School of Management (December).

Demoulin, N. T. M., \& Coussement, K. (2018). Acceptance of text-mining systems: The signaling role of information quality. Information \& Management. Advanced online publication. doi:10.1016/j. im.2018.10.006

Ducange, P., Pecori, R., \& Mezzina, P. (2018). A glimpse on big data analytics in the framework of marketing strategies. Soft Computing, 22 (1), 325-342. doi:10.1007/s00500-017-2536-4

Duyck, P., Pynoo, B., Devolder, P., Voet, T., Adang, L., Ovaere, D., \& Vercruysse, J. (2010). Monitoring the PACS implementation process in a large university hospital-discrepancies between radiologists and physicians. Journal of Digital Imaging, 23(1), 73-80. doi:10.1007/ S10278-008-9163-7

Escobar-Rodríguez, T., \& Carvajal-Trujillo, E. (2014). Online purchasing tickets for low cost carriers: An application of the unified theory of acceptance and use of technology (UTAUT) model. Tourism Management, 43, 70-88. doi:10.1016/j.tourman.2014.01.017

Falk, R. F., \& Miller, N. B. (1992). A primer for soft modeling. Akron, OH: University of Akron Press.

Featherman, M. S., \& Pavlou, P. A. (2003). Predicting e-services adoption: A perceived risk facets perspective. International Journal of Human Computer Studies, 59(4), 451-474. doi:10.1016/S1071. 5819(03)00111-3

Fishbein, M., \& Ajzen, I. (1975). Belief attitude, intention and behavior. An introduction to theory and research. Reading, MA: Addison-Wesley.
Gargallo López, B., Suárez Rodríguez, J., \& Almerich Cerveró, G. (2006). La influencia de las actitudes de los profesores en el uso de las nuevas tecnologías. Revista Espanola de Pedagogia, 64(233), 45-66.

Gefen, D., Rigdon, E. E., \& Straub, D. (2011). An update and extension to SEM guidelines for administrative and social science research. MIS Quarterly, 35(2), 3-14. doi:10.1016/j.Irp.2013.01.001

Gibson, C.F. (2004). IT-enabled business change: An approach to understanding and managing risk. MIT Sloan Working Paper No. 4520-04; CISR Working Paper No. 346. doi:10.2139/ssrn.644922

Gupta, V. K., Huang, R., \& Niranjan, S. (2010). A longitudinal examination of the relationship between team leadership and performance. Journal of Leadership \& Organizational Studies, 17(4), 335-350. doi:10.1177/1548051809359184

Hair, J. F., Sarstedt, M., Ringle, C. M., \& Mena, J. A. (2012). An assessment of the use of partial least squares structural equation modeling in marketing research. Journal of the Academy of Marketing Science, 40(3), 414-433. doi:10.1007/s11747-011-0261-6

Henseler, J., Ringle, C. M., \& Sarstedt, M. (2014). A new criterion for assessing discriminant validity in variance-based structural equation modeling. Journal of the Academy of Marketing Science, 43(1), 115135. doi:10.1007/s11747-014-0403-8

Hsieh, P. J. (2015). Healthcare professionals' use of health clouds: Integrating technology acceptance and status quo bias perspectives. International Journal of Medical Informatics, 84(7), 512-523. doi:10.1016/j.ijmedinf.2015.03.004

Huang, T. C. K., Liu, C. C., \& Chang, D. C. (2012). An empirical investigation of factors influencing the adoption of data mining tools. International Journal of Information Management, 32(3), 257-270. doi:10.1016/j.ijinfomgt.2011.11.006

Hung, Y. H., Wang, Y. S., \& Chou, S. C. T. (2007). User acceptance of e-government services. PACIS 2007 Proceedings, 97. Retrieved from http://aisel.aisnet.org/pacis2007

Ives, B., \& Olson, M. H. (2008). User involvement and MIS success: A review of research. Management Science, 30(5), 586-603. doi:/10.1287/mnsc.30.5.586

Khatibian, N., Hasan gholoi pour, T., \& Abedi Jafari, H. (2010). Measurement of knowledge management maturity level within organizations. Business Strategy Series, 11(1), 54-70. doi:10.1108/17515631011013113

Kim, D. J., Ferrin, D. L., \& Rao, H. R. (2008). A trust-based consumer decision-making model in electronic commerce: The role of trust, perceived risk, and their antecedents. Decision Support Systems, 44(2), 544-564. doi:10.1016/j.dss.2007.07.001

Kim, H.-W., \& Kankanhalli, A. (2009). Investigating user resistance to information systems implementation: A status quo bias perspective. MIS Quarterly, 33(3), 567-582. doi:10.2307/20650309

Kim, H. W., Chan, H. C., \& Gupta, S. (2007). Value-based adoption of mobile internet: An empirical investigation. Decision Support Systems, 43(1), 111-126. doi:10.1016/j.dss.2005.05.009

Kock, N. (2015). Common method bias in PLS-SEM: A full collinearity assessment approach. International Journal of E-Collaboration, 11(4), 1-10. doi:10.4018/ijec.2015100101

Kock, N., \& Lynn, G. S. (2012). Lateral collinearity and misleading results in variance-based SEM: An illustration and recommendations. Journal of the Association for Information Systems, 13(7), 546-580. 
Kwon, O., Lee, N., \& Shin, B. (2014). Data quality management, data usage experience and acquisition intention of big data analytics. International Journal of Information Management, 34(3), 387-394. I doi:10.1016/j.ijinfomgt.2014.02.002

Lai, Y., Sun, H., \& Ren, J. (2017). Understanding the determinants of big data analytics (BDA) adoption in logistics and supply chain management: An empirical investigation. International Journal of Logistics Management, 29(2), 676-703. doi. 10.1108/IJLM-06-20170153

Lapointe, L., \& Rivard, S. (2007). A triple take on information system implementation. Organization Science, 18(1), 89-107. doi:10.1287/ orsc. 1060.0225

Laumer, S., Maier, C., Eckhardt, A., \& Weitzel, T. (2016). User personality and resistance to mandatory information systems in organizations: A theoretical model and empirical test of dispositional resistance to change. Journal of Information Technology, 31(1), 67-82. doi:10.1057/ jit.2015.17

Lee, J. H., \& Song, C. H. (2013). Effects of trust and perceived risk on user acceptance of a new technology service. Social Behavior and Personality: An International Journal, 41(4), 587-597. doi:10.2224/ sbp.2013.41.4.587

Liu, X., Shin, H., \& Burns, A. C. (2019). Examining the impact of luxury brand's social media marketing on customer engagement: Using big data analytics and natural language processing. Journal of Business Research. Advanced online publication. doi: 10.1016/j. jbusres.2019.04.042

Martins, C., Oliveira, T., \& Popovič, A. (2014). Understanding the internet banking adoption: A unified theory of acceptance and use of technology and perceived risk application. International Journal of Information Management, 34(1), 1-13. doi:10.1016/j. ijinfomgt.2013.06.002

McAfee, A., \& Brynjolfsson, E. (2012). Big Data: The management revolution. Harvard Business Review, 90(10), 61-68. https://doi. org/10.1007/s12599-013-0249-5

MacKenzie, S. B., Podsakoff, P. M., \& Podsakoff, N. P. (2011). Construct measurement and validation procedures in MIS and behavioral research: Integrating new and existing techniques. MIS Quarterly, 35(2), 293-334. doi:10.2307/23044045

Norzaidi, M. D., Salwani, M. I., Chong, S. C., \& Rafidah, K. (2008). A study of intranet usage and resistance in Malaysia's port industry. Journal of Computer Information Systems, 49(1), 37-47. doi:10.1080 /08874417.2008.11645304

Nunnally, J. C. (1978). Psychometric theory (2nd edit.) Hillsdale, NJ: McGraw-hill.

Palmatier, R. W., \& Martin, K. D. (2019). Understanding and valuing customer data. In R. W. Palmatier \& K. D. Martin, The Intelligent Marketer's Guide to Data Privacy (pp. 73-92). Palgrave Macmillan, Cham. doi:10.1007/978-3-030-03724-6

Paulk, M. C., Curtis, B., Chrissis, M. B., \& Weber, C. V. (1993). Capability maturity model, version 1.1. IEEE Software, 10(4), 18-27. doi:10.1109/52.219617

Podsakoff, P. M., MacKenzie, S. B., Lee, J.-Y., \& Podsakoff, N. P. (2003). Common method biases in behavioral research: A critical review of the literature and recommended remedies. Journal of Applied Psychology, 88(5), 879-903. doi:10.1037/0021-9010.88.5.879
Podsakoff, P. M., MacKenzie, S. B., \& Podsakoff, N. P. (2012). Sources of method bias in social science research and recommendations on how to control it. Annual Review of Psychology, 63, 539--569. doi:10.1146/annurev-psych-120710-100452

Poon, E. G., Blumenthal, D., Jaggi, T., Honour, M. M., Bates, D. W., \& Kaushal, R. (2004). Overcoming barriers to adopting and implementing computerized physician order entry systems in U.S. hospitals. Health Affairs, 23(4), 184-190. doi:10.1377/hlthaff.23.4.184

Rahman, N. (2016). Factors affecting Big Data technology adoption, 0-29. Student Research Symposium. Retrieved from http://pdxscholar. library.pdx.edu/studentsymposium $\% 5$ Cnhttp://pdxscholar.library. pdx.edu/studentsymposium/2016/Presentations/10

Rehman, M. H. U., Chang, V., Batool, A., \& Wah, T. Y. (2016). Big data reduction framework for value creation in sustainable enterprises. International Journal of Information Management, 36(6), 917-928. doi:10.1016/j.jinfomgt.2016.05.013

Ringle, C. M., Wende, S., \& Becker, J. M. (2015). SmartPLS. "SmartPLS 3." Boenningstedt: SmartPLS GmbH. Retrieved from http://www. smartpls.com

Roldán, J. L., \& Sánchez-Franco, M. J. (2012). Variance-based structural equation modeling: Guidelines for using partial least squares in information systems research. In M. Mora, O. Gelman, A.L. Steenkamp \& M. Raisinghnani, Research methodologies, innovations and philosophies in software systems engineering and information systems. IGI-Global. doi:10.4018/978-1-4666-0179-6.cho10

Sivarajah, U., Kamal, M. M., Irani, Z., \& Weerakkody, V. (2017). Critical analysis of Big Data challenges and analytical methods. Journal of Business Research, 70, 263-286. https://doi.org/10.1016/j. jbusres.2016.08.001

Straub, D., Boudreau, M., \& Gefen, D. (2004). Validation guidelines for IS positivist research. Communications of the Association for Information Systems, 13(24), 380-427. doi:10.17705/1CAIS.01324

Sun, Z., Sun, L., \& Strang, K. (2018). Big Data analytics services for enhancing business intelligence. Journal of Computer Information Systems, 58(2), 162-169. doi:10.1080/08874417.2016.1220239

Urwiler, R., \& Frolick, M. N. (2008). The IT value hierarchy: Using Maslow's hierarchy of needs as a metaphor for gauging the maturity level of information technology use within competitive organizations. Information Systems Management, 25(1), 83-88. doi:10.1080/10580530701777206

Venkatesh, V., \& Bala, H. (2008). Technology acceptance model 3 and a research agenda on interventions. Decision Sciences, 39 (2), 273-315. doi:10.1111/j.1540-5915.2008.00192.x

Venkatesh, V., \& Davis, F. D. (2000). A theoretical extension of the technology acceptance model: Four longitudinal field studies. Management Science, 46(2), 186-204. doi:10.1287/ mnsc.46.2.186.11926

Venkatesh, V., Morris, M. G., Davis, G. B., \& Davis, F. D. (2003). User acceptance of information technology: Toward a unified view. MIS Quarterly, 27(3), 425-478. doi:10.2307/30036540

Venkatesh, V., Thong, J. Y. L., \& Xu, X. (2012). Consumer acceptance and use of information technology: Extending the unified theory of acceptance and use of technology. MIS Quarterly, 36(1), 157-178. doi:10.1017/CBO9781107415324.004 
Verma, S., Bhattacharyya, S. S., \& Kumar, S. (2018). An extension of the technology acceptance model in the big data analytics system implementation environment. Information Processing and Management, 54(5), 791-806. doi:10.1016/j.ipm.2018.01.004

Wedel, M., \& Kannan, P. K. (2016). Marketing analytics for datarich environments. Journal of Marketing, 80(November), 97-121. doi:10.1509/jm.15.0413

Watson, H. J. (2019). Update tutorial: Big Data analytics: Concepts, technology, and applications. Communications of the Association for Information Systems, 44(1), 364-379. doi:10.17705/1CAIS.04421

Wright, L. T., Robin, R., Stone, M., \& Aravopoulou, D. E. (2019). Adoption of Big Data technology for innovation in B2B marketing. Journal of Business-to-Business Marketing. Advanced online publication. doi: $10.1080 / 1051712 X .2019 .1611082$

Wu, Y. L., Tao, Y. H., \& Yang, P. C. (2007). Using UTAUT to explore the behavior of $3 \mathrm{G}$ mobile communication users. IEEM 2007: 2007 IEEE
International Conference on Industrial Engineering and Engineering Management (pp. 199-203). doi:10.1109/IEEM.2007.4419179

Yadegaridehkordi, E., Hourmand, M., Nilashi, M., Shuib, L., Ahani, A., \& Ibrahim, O. (2018). Influence of big data adoption on manufacturing companies' performance: An integrated DEMATEL-ANFIS approach. Technological Forecasting and Social Change, 137(March), 199-210. doi:10.1016/j.techfore.2018.07.043

Yaqoob, I., Hashem, I. A. T., Gani, A., Mokhtar, S., Ahmed, E., Anuar, N. B., \& Vasilakos, A. V. (2016). Big data: From beginning to future. International Journal of Information Management, 36(6), 1231-1247. doi:10.1016/j.ijinfomgt.2016.07.009

Yu, C.-S. (2012). Factors affecting individuals to adopt mobile banking: Empirical evidence from the UTAUT model. Journal of Electronic Commerce Research, 13(2), 104-121.

Zicari, R. (2014). Big data: Challenges and opportunities. In R. Akerkar (Ed.), Big Data Computing (pp. 103-128). Boca Raton, FL: CRC Press. doi:10.1201/b16014-5 